\title{
HUBUNGAN ANTARA KARAKTERISTIK DAN PERAN KERJA ISTRI NELAYAN DENGAN KONTRIBUSINYA DALAM PENDAPATAN RUMAH TANGGA
}

\section{The Relationship between Fisherman's Wife's Characteristics and Working Role with Their Contribution to Household Income}

\author{
Yunicha Khairiyah $^{1)}$ dan Melani Abdulkadir Sunito ${ }^{1)}$ \\ ${ }^{1)}$ Departemen Sains Komunikasi dan Pengembangan Masyarakat, Fakultas Ekologi Manusia \\ Institut Pertanian Bogor, Darmaga Bogor 16680, Indonesia \\ Email: yunichakhairiyah@gmail.com; melani@samdhana.org
}

\begin{abstract}
Fishermen's work is characterized by low and fluctuative income due to weather and season factors. Therefore, the wife's productive work and income is important contribution to household income. The objectives of this study are to (1) Describe the fisherman wife's characteristics, working roles, and income contribution ; (2) Analyze the relationship between characteristics and working roles of fisherman's wife; and (3) Analyze the relationship between characteristics and working role of fisherman's wife with their contribution to the household income. The research was conducted in Cidadap Village in Sukabumi using survey method and supported by qualitative data, and using Chi Square analysis test. Forty respondents were chosen purposively. The statistic test indicated that there is no relation between characteristic of fisherman's wife with their working role, but both the type of wife's work and the type of husband's work were significantly related to the contribution of women's income to the household.
\end{abstract}

Key words: fisherman, fisherman wife's working role ; wife's contribution to household income

\begin{abstract}
ABSTRAK
Masyarakat nelayan sampai saat ini identik dengan kemiskinan dan pendapatan tidak menentu karena faktor cuaca dan musim, sehingga istri perlu bekerja produktif dan memberi kontribusi pendapatan untuk mencukupi kebutuhan rumah tangga. Tujuan penelitian ini adalah untuk (1) Mendeskripsikan karakteristik, peran kerja, dan kontribusi pendapatan istri nelayan; (2) Menganalisis hubungan antara karakteristik dengan peran kerja istri nelayan; serta (3) Menganalisis hubungan antara karakteristik dan peran kerja istri nelayan dengan kontribusi pendapatan rumah tangga. Penelitian ini dilaksanakan di Desa Cidadap dengan metode kuantitatif yaitu survei yang didukung data kualitatif, dan menggunakan uji analisis Chi Square. Responden sebanyak 40 orang dipilih secara purposive. Hasil penelitian ini menunjukkan bahwa karakteristik istri nelayan dengan peran kerja perempuan tidak memiliki hubungan, sedangkan karakteristik dan peran kerja istri nelayan yang berhubungan dengan kontribusi pendapatan perempuan adalah jenis pekerjaan perempuan dan pekerjaan suami.
\end{abstract}

Kata kunci: Nelayan, Peran Kerja Istri Nelayan, Kontribusi Istri dalam Pendapatan Rumah Tangga

\section{PENDAHULUAN}

Indonesia merupakan negara kepulauan dengan laut seluas $96.079 \mathrm{~km}^{2}$ dan potensi perikanan yang sangat besar (Kementerian Kelautan dan Perikanan 2016). Hal ini membuat banyak orang menggantungkan hidupnya sebagai nelayan, terutama masyarakat yang tinggal di daerah pesisir. Menurut BPS (2014), jumlah rumah tangga nelayan perikanan tangkap di Indonesia sebanyak 964.231.
Pendapatan nelayan sangat tergantung pada beberapa faktor seperti cuaca dan musim, sehingga berdampak pada pendapatan yang tidak menentu. Hasil kajian dari peneliti Bahri (1995) menunjukkan bahwa usaha penangkapan ikan yang dilakukan oleh nelayan skala kecil sangat tergantung pada cuaca, musim, keterbatasan aset dan permodalan. Pada struktur masyarakat pesisir, mayoritas kepala keluarga bekerja sebagai nelayan. Dalam kondisi yang demikian maka diperlukan peran kerja istri untuk 
mencukupi ekonomi keluarga dengan melakukan pekerjaan di luar rumah (publik), (Jumaédi, 2005).

Pendapatan nelayan yang tidak menentu (fluktuatif), maka diperlukan pendapatan dari istri untuk mencukupi kebutuhan rumah tangga. Pendapatan istri diperoleh dari kerja nafkah istri. Semakin miskin nelayan, maka kontribusi istri menjadi semakin penting.

Keterlibatan perempuan dalam aktivitas sosial dan ekonomi produktif tersebut dapat memberikan kontribusi yang sangat besar terhadap perubahan kedudukan sosialnya di rumah tangga. Perempuan yang membawa penghasilannya untuk memenuhi kebutuhan rumah tangga dapat berfungsi mendekatkan kedudukannya sehingga hampir setara dengan suaminya. Perempuan yang turut serta mengontrol sumber daya yang berharga di rumah tangga, secara otomatis akan mendapatkan persamaan kedudukan, prestise, dan kekuasaan. Sebaliknya apabila perempuan hanya memberikan kontribusi sedikit untuk menyediakan kebutuhan rumah tangga, perempuan akan menempati posisi subordinat terhadap laki-laki, menurut pendapat dari Kusnadi (2006).

Besarnya potensi perikanan Indonesia ini belum mampu menjadikan sektor perikanan menjadi salah satu sektor riil yang potensial di Indonesia. Pendapatan nelayan sangat tergantung pada beberapa faktor seperti cuaca dan musim, sehingga berdampak pada pendapatan tidak menentu yang mengakibatkan keluarga nelayan masih dalam kondisi miskin. Untuk memenuhi kehidupan keluarga, maka peran dan kontribusi istri menjadi sangat penting dalam membantu mencukupi kebutuhan rumah tangga nelayan. Oleh karena itu, penting untuk mengidentifikasi bagaimana karakteristik, peran kerja, dan kontribusi pendapatan istri nelayan?

Kehidupan ekonomi nelayan yang terpuruk, biasanya istri nelayan juga turut berkorban mencari alternatif lain dalam mencari pendapatan tambahan bila keluarga mengalami kesulitan keuangan d engan menjadi buruh cuci atau buruh tani. Istri Nelayan ikut serta bekerja untuk memenuhi kebutuhan keluarga, bahkan tidak jarang harus berurusan dengan renternir atau berbagai skema pinjaman lainnya. Hal ini di perkuat oleh pernyataan Boserup (1984), bahwa sebagai salah satu anggota keluarga, istri nelayan mempunyai andil yang tidak kecil di dalam menambah pendapatan dan mewujudkan kesejahteraan keluarga. Selain bekerja di wilayah domestik (rumah tangga), istri nelayan juga turut terlibat dalam kegiatan mencari nafkah. Oleh karena itu menarik untuk diteliti, bagaimana hubungan karakteristik istri nelayan dengan peran kerja istri nelayan?

Peran dan kontribusi pendapatan perempuan menjadi sangat penting bagi kehidupan rumah tangga buruh nelayan, terutama bagi rumah tangga buruh nelayan yang masih hidup dalam kondisi kemiskinan. Seperti dijumpai pada masyarakat nelayan, yang mata pencahariannya tidak menentu. Ada waktu tertentu dimana nelayan harus melaut dan ada waktu nelayan tidak dapat melaut, karena kondisi cuaca yang tidak memungkinkan. Dalam kondisi yang demikian maka diperlukan peran isteri untuk membantu ekonomi dengan melakukan pekerjaan di luar rumah (publik), menurut Jumaédi (2005). Mereka berusaha untuk bekerja guna membantu menambah pendapatan keluarga nelayan. Maka karakteristikdan peran istri nelayan dalam menambah pendapatan keluarga nelayan menjadi alternatif untuk mengurangi kemiskinan keluarga nelayan. Oleh karena itu penting untuk menganalisis bagaimana hubungan karakteristik dan peran kerja istri nelayan dengan kontribusi pendapatan rumah tangga?

\section{PENDEKATAN TEORITIS}

\section{Nelayan dan Istri Nelayan}

Nelayan adalah orang yang hidup dari mata pencaharian hasil laut. Menurut Sastrawijaya (2002), di Indonesia para nelayan biasanya bermukim di daerah pinggir pantai atau pesisir laut. komunitas nelayan adalah kelompok orang yang bermata pencaharian hasil laut dan tinggal di desadesa pantai atau pesisir.

Raodah (2013) berpendapat bahwa, wanita nelayan adalah wanita yang hidup di lingkungan keluarga nelayan, baik istri maupun anak perempuan yang terlibat dalam aktifitas mencari nafkah untuk keluarganya. Selain bekerja di wilayah domestik (rumah tangga), juga turut terlibat dalam kegiatan mencari nafkah yakni melakukan berbagai aktifitas di bidang perikanan mulai dari pengumpulan kerang, pengolahan ikan, pedagang ikan eceran hingga menjadi pedagang perantara. Pekerjaan wanita ini dilakukan untuk memperoleh penghasilan karena pendapatan suami dari hasil melaut tidak mencukupi. Kegiatan mencari nafkah ini dianggap sebagai upaya bersama suami dalam meningkatkan taraf hidup yang lebih baik. 


\section{Karakteristik Istri Nelayan}

Karakteristik individu perempuan yang dirasa penting untuk dikaji adalah usia, pendidikan, dan curahan jam kerja (Handayani dan Artini 2009). selain karakteristik individu, menurut Haryanto (2008) karakteristik rumah tangga juga perlu dikaji. Karakteristik rumah tangga yang penting dikaji yaitu jumlah anggota keluarga, pekerjaan suami, pendapatan anggota rumah tangga lain dan family life cycle.

Adapun hubungan antara karakteristik individu dan karakteristik rumah tangga dari istri nelayan digambarkan sebagai berikut:

a) Pendidikan, menurut (Handayani dan Artini 2009), bahwa semakin tinggi tingkat pendidikan seseorang, maka akan cepat tanggap terhadap perkembangan teknologi dan kemampuan seseorang. Dihubungkan dengan tingkat pendidikan seseorang, maka tingkat pendidikan responden yang rata-rata tergolong cukup tinggi menunjukkan bahwa responden mempunyai kesadaran yang tinggi untuk berusaha meningkatkan perekonomian keluarga melalui kegiatan yang lebih bermanfaat yaitu bekerja, tanpa mengabaikan tugas sebagai ibu rumah tangga (Handayani dan Artini 2009). Semakin tinggi tingkat pendidikan semakin baik pemahaman akan mutu/nilai ekonomis barangbarang yang mesti dipilih (Rahajuni 2009). Pendidikan merupakan salah satu kebutuhan yang sangat penting bagi masyarakat terutama bagi wanita penjual ikan. Melalui pendidikan para penjual ikan diberi kesempatan untuk mengembangkan kemampuannya dan membina kehidupan dalam masyarakat. Oleh karena itu pendidikan dapat mengubah sikap dan cara berpikir wanita penjual ikan untuk lebih terampil, menurut pendapat dari Tika et al. (2015).

b) Jenis Kerja, menurut Kusnadi (2006), keterlibatan perempuan dalam sektor sosialekonomi terutama dalam sektor perikanan biasanya pada industri pengolahan dan perdagangan ikan, seperti pemindangan, pengeringan ikan, pembuatan petis, pembuatan terasi, dan perdagangan ikan segar. Tidak adanya keragaman sumber daya ekonomi dan sumber pendapatan lainnya telah membatasi akses istri nelayan untuk memperoleh penghasilan dan sektor non perikanan. c) Jumlah Tanggungan Keluarga, banyaknya jumlah anggota keluarga merupakan salah satu faktor yang mendorong seseorang untuk bekerja. Semakin banyak jumlah anggota keluarga yang tidak bekerja maka tanggungan keluarga juga lebih besar sehingga mengharuskan seseorang untuk bekerja lebih keras (Handayani dan Artini 2009). Jumlah anggota keluarga akan memengaruhi besarnya tingkat konsumsi dan beban hidup yang ditanggung. Jika jumlah tanggungan keluarga cukup banyak maka beban hidup juga semakin besar (Nesneri dan Museliza 2014).

\section{Peran Kerja Perempuan}

Menurut Aswiyati (2016), peran kerja perempuan terbagi atas tiga bagian diantaranya adalah: Peran Produktif, peran yang dihargai dengan uang atau barang yang menghasilkan uang. Contoh: penjahit, petani, guru; Peran Reproduktif, peran yang tidak dapat dihargai dengan uang atau barang. Contoh: sebagaimana peran istri seperti mengandung, melahirkan, dan menyusui; Peran Sosial, peran yang berkaitan dengan peran istri untuk mengikuti kegiatankemasyarakatan. Contoh: kegiatan pengajian, PKK.

\section{Kontribusi Pendapatan Perempuan}

Menurut T.Gilarso (2004) "Pendapatan keluarga merupakan balas karya atau jasa atau imbalan yang dip eroleh karena sumbangan yang diberikan dalam kegiatan produksi". Secara konkritnya pendapatan keluarga berasal dari :

1) Usaha itu sendiri misalnya berdagang, bertani, membuka usaha sebagai wiraswastawan.

2) Bekerja pada orang lain misalnya sebagai pegawai negeri atau karyawan.

3) Hasil dari pemilihan misalnya tanah yang disewakan dan lain-lain.

Pendapatan bisa berupa uang maupun barang misal berupa santunan baik berupa beras, fasilitas perumahan dan lain-lain. pada umumnya pendapatan manusia terdiri dari pendapatan nominal berupa uang dan pendapatan riil berupa barang.

Definisi kontribusi pendapatan perempuan menurut Farida (2011) yaitu sumbangan yang diberikan kepada rumah tangganya oleh perempuan bekerja, dengan indikator jumlah pendapatan yang diterima dan jumlah uang yang diberikan kepada rumah tangganya. Hasil yang didapat tersebut nantinya akan 
digunakan untuk mencukupi berbagai kebutuhan rumah tangga serta keluarganya. Sumbangan pendapatan oleh perempuan tersebut dapat diketahui dengan menghitung jumlah uang yang dihasilkan dari kegiatan ekonomi dan pendapatan total rumah tangga dengan menggunakan rumus:

Kontribusi perempuan $=\frac{\text { Pendapatan perempuan }}{\text { Pendapatan total ruman tangga }} \times 100 \%$

Dalam masyarakat bawah atau miskin anggota keluarga merupakan suatu sumber daya yang harus dimanfaatkan untuk dapat bekerja, baik itu untuk menyelesaikan pekerjaaan rumah tangga maupun pekerjaan yang mempunyai potensi untuk menambah ekonomi atau pendapatan keluarga, menurut Haryanto (2008).

\section{Karakteristik dan Peran Kerja Istri Nelayan dengan Kontribusinya dalam Pendapatan Rumah Tangga}

Pendapatan keluarga terdiri dari pendapatan yang diperoleh oleh suami yang bekerja ditambah dengan pendapatan yang diperoleh karena istri yang bekerja. Seorang perempuan memberikan kontribusinya terhadap rumah tangga baik dalam bentuk financial (pendapatan) maupun kontribusi yang lain seperti reproduktif (mengurus rumah tangga), pendapat dari Haryanto (2008). Beberapa studi terdahulu mengenai peran istri terhadap pendapatan keluarga. Kharisun $\mathrm{M}$ (2014), mengatakan bahwa terdapat berbagai jenis pekerjaan bagi wanita nelayan serta kontribusinya sangat penting dalam memenuhi kebutuhan rumah tangga nelayan di Kelurahan Pasie nan Tigo. Curahan waktu kerja sangat berpengaruh terhadap pendapatan wanita dan kontribusi pendapatan wanita tertinggi sebesar $75,48 \%$ dan yang terendah sebesar $26,10 \%$. Salama (2005), mengatakan bahwa peranan wanita dalam ekonomi rumah tangga nelayan pantai relatif besar.

Beberapa studi terdahulu mengenai karakteristik dan peran istri terhadap kontribusi pendapatan. Linda (2008), mengatakan bahwa terdapat berbagai jenis pekerjaan bagi wanita nelayan serta kontribusinya sangat penting dalam memenuhi kebutuhan rumah tangga nelayan di Kelurahan Pasie nan Tigo. Soeyono dan Doni (2013), mengatakan bahwa curahan waktu kerja, jumlah tanggungan keluarga. Tingkat pendidikan dan lama bekerja berpengaruh positif terhadap pendapatan buruh wanita pada PT Gading Mas Indonesia Tobacco. Farida L (2011), mengatakan bahwa pendidikan sangat berpengaruh terhadap pendapatan wanita dan kontribusi pendapatan wanita tertinggi sebesar $75,48 \%$ dan yang terendah sebesar $26,10 \%$. salama (2005),mengatakan bahwa peranan wanita dalam ekonomi rumah tangga nelayan relatif besar. Kharisun M. (2014), mengatakan faktor yang memengaruhi pendapatan keluarga nelayan adalah jumlah anggota keluarga dan karakteristik wanita nelayan bekerja sebanyak $45,45 \%$.

\section{Kerangka Pemikiran}

Pendapatan keluarga lazimnya merupakan kewajiban suami sebagai pencari nafkah. Seorang nelayan yang kebanyakan seorang laki-laki seharusnya mampu untuk memenuhi kebutuhan keluarganya. Akan tetapi, dengan keadaan nelayan yang masih dalam keadaan miskin menuntut anggota keluarga turut serta dalam memenuhi kebutuhan keluarganya. Terutama istri, yang memberikan waktunya untuk berprofesi ganda, yaitu sebagai ibu rumah tangga dan sebagai wanita karir. Di Kecamatan Simpenan Desa Cidadap masih banyak istri-istri nelayan yang disaat suaminya melaut, mereka berusaha untuk mendapatkan pendapatan tambahan baik dari sektor perikanan maupun diluar sektor perikanan.

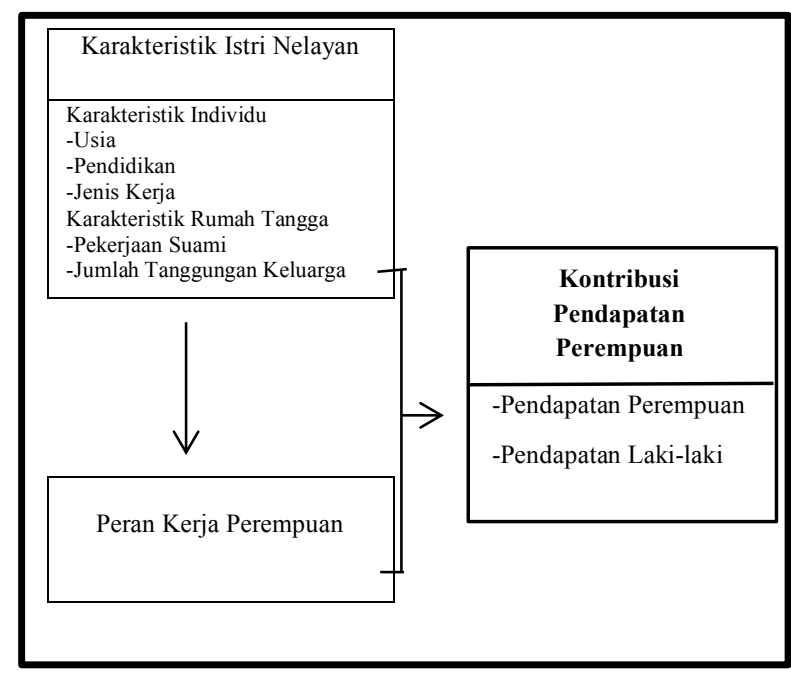

\section{: Berhubungan}

Gambar 1 Kerangka analisis hubungan antara karakteristik dan peran kerja istri nelayan dengan kontribusinya dalam pendapatan rumah tangga

Oleh karena itu, Faktor yang memengaruhi kontribusi pendapatan perempuan terdiri dari lima variabel yaitu usia, tingkat pendidikan, jenis pekrjaan istri, pekerjaan suami, jumlah tanggungan keluarga. 
Semakin muda usia responden, semakin tinggi pendidikan responden, semakin ganda pekerjaan responden, semakin suami memiliki pekerjaan sampingan dan semakin banyak jumlah tanggungan keluaraga maka semakin produktif peran kerjanya dan kontribusi pendapatan semaki tinggi. Selain itu peran kerja berdasarkan jam kerja juga memengaruhi kontribusi pendapatan perempuan, semakin produktif perempuan maka kontribusi pendapatan perempuan semakin tinggi.

\section{METODE PENELITIAN}

Penelitian ini menggunakan metode penelitian kuantitatif dengan pendekatan survei dan dikuatkan data kualitatif. Metode kuantitatif untuk menjawab pertanyaan karakteristik, peran dan kontribusi pendapatan istri nelayan.

Sementara itu, data kualitatif untuk mendukung penelitian kuantitatif. Penelitian kualitatif dilakukan dengan menggunakan wawancara mendalam kepada responden maupun informan menggunakan panduan pertanyaan dan dipaparkan dalam bentuk catatan harian lapang. Informasi yang diperoleh melalui data kualitatif ini digunakan untuk mendukung dan sebagai interpretasi terhadap data yang didapatkan dari metode kuantitatif mengenai karakteristik dan peran kerja istri nelayan dengan kontribusinya dalam pendapatan rumah tangga

Penelitian ini dilakukan di Kampung Cihurang dan Mariuk, Desa Cidadap, Kabupaten Sukabumi Provinsi Jawa Barat. Pemilihan lokasi dilakukan secara sengaja (purposive) berdasarkan survei awal menurut pengelola nelayan (UW, 79 Tahun) bahwa pada lokasi tersebut hampir 30\% warga masyarakat bekerja sebagai nelayan dan istri nelayan di desa tersebut banyak yang bekerja, sehingga terdapat istri nelayan yang bekerja. Data yang digunakan dalam penelitian ini adalah data primer dan data sekunder. Data primer didapatkan langsung di lapang dengan cara wawancara menggunakan kuesioner, observasi dan wawancara mendalam menggunakan panduan wawancara. Sementara itu, data sekunder diperoleh melalui studi literatur dan informasi tertulis yang dapat digunakan dan sesuai dengan topik penelitian.

Populasi penelitian ini adalah istri nelayan di Desa Cidadap Kampung Cihurang dan Mariuk Pelabuhan Ratu Sukabumi. Unit penelitian adalah istri nelayan yang bekerja. Responden secara purposive dimana penentuan sampling dilakukan sesuai dengan kategori responden yang telah ditentukan. Kriteria keluarga nelayan yang dijadikan sampel adalah suami bekerja sebagai buruh nelayan atau sebagai buruh nelayan yang memiliki pekerjaan sampingan. Kriteria responden adalah istri nelayan yang bekerja, dengan suami sebagai buruh nelayan (kelompok pekerjaan suami pertama) atau sebagai buruh nelayan yang memiliki pekerjaan sampingan (kelompok pekerjaan suami kedua. Alasan peneliti menggunakan sampling purposive dikarenakan responden disesuaikan dengan kriteria responden di atas. Jumlah responden dalam penelitian ini sebanyak 40 responden adalah istri nelayan yang bekerja dari dua kelompok nelayan yaitu buruh nelayan dan buruh nelayan dengan pekerjaan sampingan.

Data kuantitatif diolah menggunakan aplikasi Microsoft Excel 2010 dan SPSS. Pembuatan tabel frekuensi, diagram, serta tabel tabulasi silang untuk melihat data awal responden untuk masing-masing variabel secara tunggal menggunakan aplikasi Microsoft Excel 2010. Kemudian SPSS version 16.0 digunakan untuk membantu dalam uji statistik yang akan menggunakan uji chi square.

\section{HASIL DAN PEMBAHASAN}

\section{Karakteristik, Peran Kerja Dan Kontribusi Pendapatan Istri Nelayan}

\section{Karakteristik Istri Nelayan}

Karakteristik merupakan ciri atau sifat dalam diri seseorang. Karakteristik istri nelayan dalam penelitian ini digunakan untuk melihat hubungan dengan peran kerja produktif dan reproduktif perempuan (berdasarkan lama jam kerja), selain untuk melihat hubungan peran kerja perempuan, karakteristik istri nelayan penting untuk melihat hubungan dengan kontribusi pendapatan perempuan. Dengan demikian, mengetahui variabel-variabel dalam karakteristik istri nelayan sangat penting.

\section{Karakteristik Individu}

Responden dalam penelitian ini adalah istri nelayan di Desa Cidadap yang bekerja nafkah, sebanyak 40 responden. Mereka terdiri dari dua kelompok pekerjaan suami, yaitu kelompok buruh nelayan dan kelompok buruh nelayan dengan pekerjaan sampingan. Karakteristik individu dari penelitian ini terdiri dari usia, tingkat pendidikan dan jenis pekerjaan istri.

Berdasarkan data pada Tabel 1, dapat kita ketahui bahwa sebanyak 7.5 persen istri nelayan termasuk dalam kategori usia dewasa muda, selain itu sebanyak 75 persen istri nelayan termasuk kedalam kategori 
usia dewasa menengah dan sebanyak 17.5 persen istri nelayan termasuk kedalam kategori usia tua. Responden yang memiliki persentase tertinggi di Desa Cidadap yaitu kategori usia 26 sampai 45 tahun.

Tabel 1 Jumlah dan persentase responden berdasarkan usia, Desa Cidadap, Palabuhan Ratu, Kabupaten Sukabumi, tahun 2017

\begin{tabular}{ccc}
\hline Usia & $\begin{array}{c}\text { Jumlah } \\
\text { (n) }\end{array}$ & $\begin{array}{c}\text { Persentase } \\
(\%)\end{array}$ \\
\hline Dewasa muda ( $\leq 25$ tahun) & 3 & 7.5 \\
Dewasa menengah (26-45 & 30 & 75.0 \\
tahun) & & 17.5 \\
\hline Tua (46+ tahun) & 7 & 100.0 \\
\hline Total & 40 & \\
\hline
\end{tabular}

Keterangan: Dewasa muda dibawah/sama dengan 25 tahun; Dewasa menengah 26 sampai 45 tahun; dan usia Tua lebih dari 46 tahun.

\section{Pendidikan}

Rata-rata pendidikan responden di Desa Cidadap adalah lulusan SD, pendidikan tidak di anggap terlalu penting bagi mereka dan orang tua mereka karena baik berpendidikan tinggi atau tidak, tidak akan memengaruhi faktor apa saja bagi mereka. Sudah dapat makan saja bagi mereka sudah cukup, tidak perlu berpendidikan tinggi-tinggi.

Tabel 2 Jumlah dan persentase responden berdasarkan tingkat pendidikan, Desa Cidadap, Palabuhan Ratu, Kabupaten Sukabumi, tahun 2017

\begin{tabular}{lcc}
\hline Tingkat Pendidikan & $\begin{array}{c}\text { Jumlah } \\
(\mathrm{n})\end{array}$ & $\begin{array}{c}\text { Persentase } \\
(\%)\end{array}$ \\
\hline Tidak tamat SD & 6 & 15.0 \\
SD - SMP tidak tamat & 25 & 62.5 \\
Tamat SMP ++ & 9 & 22.5 \\
\hline Total & 40 & 100.0 \\
\hline
\end{tabular}

Keterangan: Rendah yaitu tidak tamat SD; Sedang yaitu SD SMP tidak tamat; dan Tinggi Tamat SMP ++ .

Berdasarkan data pada Tabel 2, dapat kita ketahui bahwa rata-rata pendidikan istri nelayan adalah tamat SD. Sebanyak 15 persen memiliki tingkat pendidikan yang rendah, sebanyak 62.5 persen memiliki tingkat pendidikan yang sedang, dan sebanyak 22.5 persen memiliki tingkat pendidikan yang terkategori tinggi. Berbagai macam alasan yang di katakan oleh responden mulai dari keterbatasan dana dan dirasakan sudah cukup pendidikan sampai SD. Meski pada generasi orangtua pendidikan tidak dipandang penting, hal itu mengalami perubahan pada pendidikan anak mereka. Hal tersebut diperkuat dengan pendapat dari salah satu responden BP (37 Tahun) berikut:

“...kalo pendidikan namanya dikampung neng,
jaman dulu mah gak terlalu ment ingin sekolah
neng. Saya aja cuma tamatan SD udah lulus SD
yaudah bantuin orang tua aja dirumah sampe
nikah. Udah lulus SD aja bersyukur banget
disini mah neng namanya orang gak punya,
terus sekolah masih mending banget. Suami
saya juga SD nya gak sampe tamat. Tapi saya
sekarang mentingin anak buat gak kaya saya
neng cuma lulusan SD saja, pokonya anak saya
mah minimal lulusan SMA deh apa aja saya
korbanin buat pendidikan anak mah...” (Ibu
BP, 37 Tahun)

\section{Jenis Pekerjaan Istri Nelayan}

Pandangan bahwa pekerjaan istri nelayan hanya mengurus rumah tangga (reproduktif) di patahkan oleh gambaran berikut. Dari hasil penelitian, istri nelayan yang berusaha sendiri ada berbagai macam diantaranya adalah berjualan baju, membuat kripik, membuat ikan asin. Selain itu, istri nelayan dengan kategori buruh diantaranya adalah buruh tani, buruh pabrik, asisten rumah tangga, buruh cuci, dan pekerja restoran. Sedangkan istri nelayan dengan kategori pekerjaan ganda yaitu istri nelayan yang bekerja sekaligus pada kedua macam pekerjaan tersebut.

Tabel 3 Jumlah dan persentase responden berdasarkan jenis pekerjaan, Desa Cidadap, Palabuhan Ratu, Kabupaten Sukabumi, tahun 2017

\begin{tabular}{lcc}
\hline \multicolumn{1}{c}{ Jenis Pekerjaan } & Jumlah (n) & Persentase (\%) \\
\hline Buruh & 18 & 45.0 \\
Berusaha Sendiri & 20 & 50.0 \\
Ganda & 2 & 5.0 \\
\hline Total & 40 & 100.0 \\
\hline
\end{tabular}

Berdasarkan data pada tabel 3, dapat kita ketahui bahwa dengan persentase hampir seimbang antara istri nelayan bekerja pada jenis pekerjaan berusaha sendiri 50 persen dengan menjadi buruh 45 persen. Ada dua responden yang jenis pekerjaannya berusaha sendiri sekaligus buruh.

\section{Karakteristik Rumah Tangga}

Karakteristik rumah tangga dalam penelitian ini yaitu melihat karakter dari rumah tangga nelayan seperti 
pekerjaan suami dan jumlah tanggungan keluarga. Pekerjaan suami sengaja peneliti bagi kedalam dua kategori yaitu buruh nelayan dan buruh nelayan dengan pekerjaan sampingan, hal ini dikarenakan peneliti ingin melihat apakah ada perbedaan pendapatan dan lainnya untuk kedua pekerjaan tersebut. Sedangkan jumlah tanggungan keluarga peneliti gunakan untuk mengukur apakah jumlah orang yang dalam suatu keluarga memengaruhi peran kerja serta pendapatan dalam rumah tangga nelayan.

\section{Pekerjaan Suami}

Pekerjaan nelayan (suami dari responden) di Desa Cidadap terdiri atas dua kategori yaitu buruh nelayan dan buruh nelayan dengan usaha sampingan. Setiap hari kecuali jumat buruh nelayan melaut. Hari jumat mereka tidak melaut karena ada shalat jumat sehingga dipandang hari libur. Nelayan buruh berangkat dari rumah masing-masing (naik mobil pick up/transportasi umum ke pelabuhan atau tempat pendaratan perahu) yaitu setelah sholat subuh dan pulang setelah dzuhur jika tangkapan sudah cukup, tetapi jika tangkapan kurang maka mereka bisa pulang maghrib. Buruh nelayan dengan usaha sampingan dalam penelitian yaitu nelayan yang menambah penghasilannya dengan bekerja sepulang melaut atau ketika sedang tidak musim ikan di laut. Pekerjaan sampingan tersebut antara lain adalah buruh tani, pengambil pasir, buruh bangunan, dan tukang ojek.

Tabel 4 Jumlah dan persentase responden berdasarkan pekerjaan suami, Desa Cidadap, Palabuhan Ratu, Kabupaten Sukabumi, tahun 2017

\begin{tabular}{lcc}
\hline Pekerjaan Suami & $\begin{array}{c}\text { Jumlah } \\
\text { (n) }\end{array}$ & $\begin{array}{c}\text { Persentase } \\
(\%)\end{array}$ \\
\hline $\begin{array}{l}\text { Buruh Nelayan } \\
\text { Buruh Nelayan dengan }\end{array}$ & 20 & 50.0 \\
Usaha Sampingan & 20 & 50.0 \\
\hline Total & 40 & 100.0 \\
\hline
\end{tabular}

Bagi pak MS (38 Tahun), mencari pekerjaan sampingan untuk menambah penghasilan hanya bisa dilakukakannya pada saat libur melaut karena sepi tenaga untuk melakukan pekerjaan yang lain di darat. Penghasilan melaut menghabiskan banyak waktu dan tenaga, sedangkan penghasilan yang diperoleh tidak pasti.

Cerita bapak ES yang bekerja sebagai nelayan saja karena tidak kuat bekerja lainnya faktor usia.
Sedangkan bapak OP selain bekerja nelayan juga berburuh tani dan bapak IQ bekerja sebagai buruh nelayan dan pengojek. Keduanya mengemukakan menambah pendapatan dan adanya kesempatan kerja di luar perikanan sebagai alasan bekerja. Hal tersebut diperkuat dengan pendapat dari beberapa suami responden yaitu:

"Saya melaut dari pagi sampe dzuhur, ya kalo
dapet ikan saya pulang neng. Kalo belum dapat
ikan mah lanjut terus ngambil sampe ashar
atau maghrib. Kalo ikan saya sering banget
juga gak dapet sama sekali, ya mau gimana
lagi atuh neng namanya udah dari kecil
kerjaannya ngambil ikan dilaut jadi mau dapat
ikan atau engga saya tetap kerja sebagai
nelayan. Kalo sampingan mah engga neng,
badan saya udah gak kuat kerjaan yang lain..."
(Bapak ES,57 Tahun)

\section{Jumlah Tanggungan Keluarga}

Tanggungan keluarga dalam penelitian ini di lihat berdasarkan usia anak kurang dari 15 tahun dan usia orang tua yang apa bila usia lebih dari sama dengan 65 tahun maka termasuk ke dalam tanggungan keluarga. Rata-rata jumlah tanggungan keluarga dalam satu keluarga pada penelitian ini yaitu empat orang.

Rata-rata jam kerja untuk kegiatan reproduktif yaitu 4 jam per hari, sedangkan rata-rata jam kerja untuk kegiatan produktif yaitu 8 jam per hari, dan rata-rata jam kerja total antara produktif dengan reproduktif adalah 12 jam per hari.

Tabel 5 Jumlah dan persentase responden berdasarkan peran kerja perempuan, Desa Cidadap, Palabuhan Ratu, Kabupaten Sukabumi, tahun 2017

\begin{tabular}{lcc}
\hline $\begin{array}{c}\text { Peran Kerja } \\
\text { Perempuan }\end{array}$ & $\begin{array}{c}\text { Jumlah } \\
(\mathrm{n})\end{array}$ & $\begin{array}{c}\text { Presentase } \\
(\%)\end{array}$ \\
\hline Rendah & 6 & 15.0 \\
Sedang & 28 & 60.0 \\
Tinggi & 6 & 15.0 \\
\hline Total & 40 & 100.0 \\
\hline
\end{tabular}

Berdasarkan data pada Tabel 5, dapat kita ketahui bahwa lebih dari setengah istri nelayan di Desa Cidadap memiliki peran kerja yang sedang.

\section{Kontribusi Pendapatan Perempuan}

\section{Pendapatan Perempuan}


Masih banyak orang yang beranggapan bahwa perempuan kodratnya hanya di dapur, mengurus anak dan suami. Padahal banyak perempuan walaupun mengerjakan tugas dapur dan lainnya tetapi masih bisa bekerja dan menghasilkan pendapatan uang untuk keluarganya. Hal ini dibuktikan oleh istri nelayan di Desa Cidadap yang setiap harinya bekerja walaupun suami mereka juga bekerja.

Pendapatan istri nelayan dihitung dari pendapatan per hari atau perminggu. Pendapatan ini kemudian dijumlahkan sehingga mendapatkan total pendapatan perempuan per bulan. Rata-rata pendapatan istri nelayan di Desa Cidadap ini dalam satu bulan adalah Rp.1.065.000.

Tabel 6 Jumlah dan persentase responden berdasarkan pendapatan perempuan, Desa Cidadap, Palabuhan Ratu, Kabupaten Sukabumi, tahun 2017

\begin{tabular}{lcc}
\hline Pendapatan Perempuan (Rp) & $\begin{array}{c}\text { Jumlah } \\
(\mathrm{n})\end{array}$ & $\begin{array}{c}\text { Presentase } \\
(\%)\end{array}$ \\
\hline$<=615.000$ & 11 & 27.5 \\
$615.000-1.515 .000$ & 23 & 57.5 \\
$>1.515 .000$ & 6 & 15.0 \\
\hline Total & 40 & 100.0
\end{tabular}

Keterangan: Rendah dibawah/sama dengan Rp.615.000; Sedang Rp.615.000 sampai Rp.1.515.000 ; dan Tinggi lebih dari Rp.1.515.000.

Berdasarkan data pada Tabel 6, dapat kita ketahui bahwa lebih dari setengah responden berpendapatan sedang yaitu Rp.615.000 sampai Rp.1.515.000. Hal tersebut diperkuat dengan pendapat dari beberapa responden yaitu:

\begin{abstract}
"Saya mah kadang kerja apa aja neng, yang penting sehari-hari kebutuhan terpenuhi. Apalagi harga-harga sembako sekarang udah gak bisa ditawar lagi mahalnya minta ampun. kalo ngandelin dari suami doang mah gak akan cukup. Kasian juga anak-anak. Saya aja belabelain jadi buruh dilahan orang kadang dapet 35 ribu atau 40 ribu, kadang kuli ngarogol (bersihin bawang merah) sekilo 500 perak, saya biasa dapet 15 kilo dari pagi sampe sore..." (Ibu AI,39 Tahun)
\end{abstract}

\section{Pendapatan Laki-laki}

Pendapatan laki-laki yang peneliti dapatkan adalah pendapatan per hari karena ketika peneliti menanyakan berapa pendapatan per bulan maka jawabannya tidak menentu dan tidak tahu di karenakan pendapatan yang di dapatkan tidak menentu akibat faktor cuaca atau musim, sehingga peneliti harus menanyakan pendapatan yang di peroleh dalam seminggu atau per hari dan setelah peneliti mendapatkan informasi mengenai pendapatannya, peneliti menjumlahkan sehingga mendapatkan total pendapatan laki-laki per bulan.

Rata-rata pendapatan laki-laki yang bekerja sebagai buruh nelayan ataupun buruh nelayan dengan pekerjaan sampingan dalam satu bulan adalah Rp.1.930.750 sehingga peneliti mengkategorikan kedalam tiga kategori yaitu tinggi, sedang, dan rendah. dengan menggunakan perhitungan rumus standar deviasi dalam satuan rupiah berdasarkan besaran rata-rata upah yang didapatkan oleh laki-laki.

Tabel 7 Jumlah dan persentase responden berdasarkan pendapatan laki-laki, Desa Cidadap, Palabuhan Ratu, Kabupaten Sukabumi, tahun 2017

\begin{tabular}{lcc}
\hline Pendapatan Laki-laki (Rp) & $\begin{array}{c}\text { Jumlah } \\
(\mathrm{n})\end{array}$ & $\begin{array}{c}\text { Presentase } \\
(\%)\end{array}$ \\
\hline$\leq 1.610 .213$ & 7 & 17.5 \\
$1.610 .213-2.251 .184$ & 24 & 60.0 \\
$>2.251 .184$ & 9 & 22.5 \\
\hline Total & 40 & 100.0 \\
\hline
\end{tabular}

Keterangan: Rendah dibawah/sama dengan Rp.1.610.213; Sedang Rp.1.610.213 sampai Rp. 2.251.184; dan Tinggi lebih dari Rp.2.251.184.

Berdasarkan data pada Tabel 7, dapat kita ketahui bahwa sebanyak 17.5 persen yaitu termasuk kedalam kategori yang memiliki pendapatan rendah, sebanyak 60 persen yaitu termasuk kedalam kategori yang memiliki pendapatan sedang dan sebanyak 22.5 persen yaitu termasuk kedalam kategori yang memiliki pendapatan tinggi. Terbukti bahwa di Desa Cidadap dengan jumlah 40 responden, pendapatan suami dengan presentase tertinggi berada pada kategori pendapatan sedang atau 1.610.213 sampai 2.251.184, sedangkan pendapatan suami dengan presentase terendah berada pada kategori rendah atau $\leq 1.610 .213$.

\section{Kontribusi Perempuan}

Keluarga yang hidup dalam kondisi miskin melakukan suatu strategi untuk dapat bertahan di tengah keterbatasan, sehingga kontribusi perempuanlah yang secara ekonomi dapat menambah penghasilan dalam suatu keluarga. Seperti halnya di Desa Cidadap ini, kontribusi perempuan diperoleh dari pendapatan perempuan dibagi pendapatan total rumah tangga (suami dan istri) dan di persentasekan sehingga menjadi ke dalam tiga tingkatan seperti pada tabel di bawah ini. 
Tabel 8 Jumlah dan persentase responden berdasarkan kontribusi pendapatan perempuan, Desa Cidadap, Palabuhan Ratu, Kabupaten Sukabumi, tahun 2017

\begin{tabular}{lcc}
\hline Kontribusi Perempuan (\%) & $\begin{array}{c}\text { Jumlah } \\
(\mathrm{n})\end{array}$ & $\begin{array}{c}\text { Presentase } \\
(\%)\end{array}$ \\
\hline$\leq 24$ & 9 & 22.5 \\
$24-42$ & 23 & 57.5 \\
$>42$ & 8 & 20.0 \\
\hline Total & 40 & 100.0
\end{tabular}

Keterangan: Rendah dibawah/sama dengan 24 persen; Sedang 24 sampai 42 persen; dan Tinggi lebih dari 42 tahun.

Berdasarkan data pada Tabel 8, dapat kita ketahui bahwa sebanyak 22.5 persen termasuk kedalam tingkat kontribusi rendah, sebanyak 57.5 persen termasuk kedalam tingkat kontribusi sedang, dan sebanyak 20 persen termasuk kedalam tingkat kontribusi tinggi. Hal ini terlihat bahwa di Desa Cidadap dengan jumlah 40 responden, mayoritas kontribusi istri nelayan yaitu sedang. sedangkan kontribusi istri nelayan dengan presentase terendah berada pada kontribusi tinggi.

Sebagaimana dikemukakan oleh responden yaitu ibu BA menceritakan bahwa ibu BA berkontribusi namun tidak sampai setengah dari pendapatan suaminya.

\begin{abstract}
"Saya kerja juga neng sama kaya suami, tapi ya penghasilan saya mah gak sampe sama kaya suami saya neng namanya juga gak bisa apaapa cuma ngandelin jadi buruh aja neng. Yang penting saya berkontribusi buat menuhin kebutuhan rumah tangga saya neng, ya walaupun kontribusi penghasilan saya gak seberapa neng. Lagian suami saya mah gak nuntut saya untuk berkontribusi juga dalam hal keuangan atau pemenuhan kebutuhan. Saya sendiri aja yang berpikir untuk ngebantuin suami saya neng..." (Ibu BA, 35 Tahun)
\end{abstract}

\section{Hubungan Karakteristik dengan Peran Kerja Istri Nelayan}

\section{Karakteristik Individu dengan Peran Kerja Istri Nelayan}

Hubungan karakteristik dan peran kerja perempuan dapat diteliti dengan melihat hubungan antara variabel Karakteristik dan peran kerja perempuan dalam rumah tangga. sehingga dapat diketahui apakah kedua variabel di duga tersebut cukup signifikan. Berikut disajikan hubungan kedua variabel tersebut pada tabel.

\section{Hubungan Usia dengan Peran Kerja Istri Nelayan}

Faktor yang memengaruhi keterlibatan istri nelayan dalam kegiatan ekonomi adalah usia. Usia seseorang cenderung ikut memengaruhi peran kerja, semakin bertambah usia seseorang maka semakin produktif pula peran kerja yang di lakukan oleh istri nelayan. Sehingga perlunya penelitian di Desa Cidadap untuk melihat apakah usia memengaruhi peran kerja istri nelayan, hal tersebut dapat di lihat pada Tabel 9.

Tabel 9 Jumlah dan persentase responden berdasarkan jenis usia dengan peran kerja perempuan, Desa Cidadap, Palabuhan Ratu, Kabupaten Sukabumi, tahun 2017

\begin{tabular}{lcccc}
\hline & \multicolumn{3}{c}{ Peran Kerja Istri Nelayan } & \\
\cline { 2 - 4 } Usia & Rendah & $\begin{array}{c}\text { Sedan } \\
\text { g }\end{array}$ & $\begin{array}{c}\text { Ting } \\
\text { gi }\end{array}$ & \\
\cline { 2 - 4 } & $\%$ & $\%$ & $\%$ & $\%$ \\
\hline Dewasa Muda & 0.0 & 100.0 & 0.0 & 100.0 \\
Dewasa & 46.7 & 53.3 & 0.0 & 100.0 \\
Menengah & 14.3 & 71.4 & 14.3 & 100.0 \\
Tua & & & & \\
Keterangan: Uji chi square: nilai signifikansi $=0.562$ &
\end{tabular}

Berdasarkan tabel di atas terlihat bahwa tidak ada kecenderungan hubungan, terbukti bahwa pada kategori sedang peran kerja yang lebih dominan terdapat pada pada usia dewasa muda. Hal ini terlihat bahwa para perempuan dalam penelitian lebih dominan untuk bekerja pada pekerjaan yang tergolong produktif, walaupun para istri lebih giat untuk bekerja pada pekerjaan produktif tetapi para istri juga mengerjakan pekerjaan rumah atau reproduktifnya oleh mereka sendiri tetapi tidak cukup dominan, selain itu berdasarkan tabel di atas usia perempuan tidak memengaruhi perempuan dalam berperan kerja karna terlihat bahwa dengan kategori usia manapun mereka tetapi giat untuk bekerja produktif. Hal tersebut dapat diperkuat oleh pernyataan seorang responden yang menyatakan bahwa usia tidak ada hubungannya dengan peran kerja, yaitu:

\footnotetext{
“...saya kerja gak mandang umur saya neng, yang penting saya masih kuat kerja, saya masih sehat, dan saya masih mampu untuk bekerja. Paling ya namanya udah tua paling pendapatan saya sedikit. Tapi saya tidak pernah pantang menyerah untuk bekerja,
} 
kasian cucu saya yang masih sekolah neng. Kalo saya gak maksain kerja bayaran dan tambahan uang lainnya bagaimana. Gak mungkin saya cuma ngandelin uang suami saya..." (Ibu ES, 61 Tahun)

\section{Hubungan Tingkat Pendidikan dengan Peran Kerja Istri Nelayan}

Pendidikan merupakan faktor yang sangat penting dalam kehidupan individu, masyarakat, bangsa dan negara, karena pendidikan sangat menentukan tingkat kualitas sumberdaya manusia. Semakin tinggi tingkat pendidikan seseorang, maka akan semakin tinggi pula tingkat kualitas orang tersebut.

Tabel 10 Persentase responden berdasarkan pendidikan dengan peran kerja perempuan, Desa Cidadap, Palabuhan Ratu, Kabupaten Sukabumi, tahun 2017

\begin{tabular}{lcccc}
\hline \multirow{2}{*}{ Pendidikan } & \multicolumn{3}{c}{ Peran Kerja Perempuan } & \multirow{2}{*}{ Total } \\
\cline { 2 - 4 } & Rendah & Sedang & Tinggi & \\
\cline { 2 - 4 } & $\%$ & $\%$ & $\%$ & $\%$ \\
\hline Rendah & 14.3 & 85.7 & 0.0 & 100.0 \\
Sedang & 41.7 & 54.2 & 5.1 & 100.0 \\
Tinggi & 44.4 & 55.6 & 0.0 & 100.0 \\
\hline Keterangan: Uji chi square: nilai signifikansi $=0.393$ &
\end{tabular}

Berdasarkan tabel 10 terlihat bahwa tidak ada kecenderungan hubungan, terbukti bahwa pada kategori peran kerja sedang terdapat pada tingkat pendidikan rendah. Hal ini karena pendidikan tidak menghambat aktivitas para istri nelayan di Desa Cidadap dalam bekerja produktif, pendidikanpun tidak menjadi prasyarat untuk dapat menambah pendapatan istri nelayan. Apapun pendidikan yang di tempuh oleh mereka, tidak memengaruhi peran kerja perempuan.

\section{Hubungan Jenis Pekerjaan dengan Peran Kerja Perempuan}

Berdasarkan Tabel 10 terlihat bahwa tidak ada kecenderungan hubungan, terbukti bahwa persentase tertinggi terdapat pada kategori peran kerja sedang terdapat pada jenis pekerjaan buruh. Hal ini di karenakan para perempuan di Desa Cidadap yang bekerja sebagai buruh masih bisa mengerjakan pekerjaan reproduktif walaupun mereka bekerja produktif tetapi tidak menutup kemungkinan istri nelayan lebih memprioritaskan pekerjaan reproduktif.
Tabel 10 Persentase responden berdasarkan jenis pekerjaan dengan peran kerja perempuan, Desa Cidadap, Palabuhan Ratu, Kabupaten Sukabumi, tahun 2017

\begin{tabular}{|c|c|c|c|c|}
\hline \multirow{3}{*}{ Jenis Pekerjaan } & \multicolumn{3}{|c|}{ Peran Kerja Perempuan } & \multirow[b]{2}{*}{ Total } \\
\hline & Rendah & $\begin{array}{c}\text { Sedan } \\
\mathrm{g}\end{array}$ & Tinggi & \\
\hline & $\%$ & $\%$ & $\%$ & $\%$ \\
\hline Buruh & 27.8 & 66.7 & 5.5 & 100.0 \\
\hline Berusaha & 45 & 55.0 & 0.0 & 100.0 \\
\hline $\begin{array}{l}\text { Sendiri } \\
\text { Ganda }\end{array}$ & 50.0 & 50.0 & 0.0 & 100.0 \\
\hline
\end{tabular}

\section{Hubungan Pekerjaan Suami dengan Peran Kerja Istri Nelayan}

Hubungan karakteristik rumah tangga dan peran kerja perempuan dapat diteliti dengan melihat hubungan antara variabel karakteristik pekerjaan suami dan peran kerja perempuan dalam rumah tangga. sehingga dapat diketahui apakah kedua variabel di duga tersebut terbukti cukup signifikan. Berikut disajikan hubungan kedua variabel tersebut pada tabel.

Tabel 11 Persentase responden berdasarkan pekerjaan suami dengan peran kerja perempuan, Desa Cidadap, Palabuhan Ratu, Kabupaten Sukabumi, tahun 2017

\begin{tabular}{lcccc}
\hline \multirow{2}{*}{$\begin{array}{l}\text { Pekerjaan } \\
\text { Suami }\end{array}$} & \multicolumn{3}{c}{ Peran Kerja Perempuan } & \multirow{2}{*}{ Total } \\
\cline { 2 - 4 } & Rendah & Sedang & Tinggi & \\
\cline { 2 - 4 } & $\%$ & $\%$ & $\%$ & $\%$ \\
\hline Buruh Nelayan & 40.0 & 60.0 & 0.0 & 100.0 \\
$\begin{array}{l}\text { Buruh Nelayan } \\
\text { dengan Usaha }\end{array}$ & 35.0 & 60.0 & 5.0 & 100.0 \\
Sampingan & & & & \\
Keterangan: Uji chi square: nilai signifikansi $=0.789$ &
\end{tabular}

Berdasarkan Tabel 11 terlihat bahwa tidak ada kecenderungan hubungan, terbukti bahwa kelompok produktif terdapat pada pekerjaan suami yaitu buruh nelayan dengan usaha sampingan. Hal ini karena, istri nelayan di Desa Cidadap sudah terbiasa bekerja produktif sehingga walaupun suaminya memiliki pekerjaan sampingan tetapi mereka tetap giat untuk bekerja produktif.
6. Hubungan Tanggungan Keluarga dengan Peran Kerja Istri Nelayan 
Pada umumnya keluarga nelayan untuk memcukupi kebutuhan hidup sehari-hari sangatlah kurang apalagi jika anggota keluarganya banyak, sehingga pendapatan mereka sangatlah minim. Oleh karena itu, istri nelayan di samping sebagai ibu rumah tangga peranannya sangatlah besar pula untuk memenuhi pendapatan rumah tangga.

Tabel 12 Persentase responden berdasarkan tanggungan keluarga dengan peran kerja perempuan, Desa Cidadap, Palabuhan Ratu, Kabupaten Sukabumi, tahun 2017

\begin{tabular}{lcccc}
\hline \multirow{2}{*}{$\begin{array}{l}\text { Tanggungan } \\
\text { Keluarga }\end{array}$} & \multicolumn{3}{c}{ Peran Kerja Perempuan } & \multirow{2}{*}{ Total } \\
\cline { 2 - 4 } & Rendah & Sedang & Tinggi & \\
\cline { 2 - 4 } & $\%$ & $\%$ & $\%$ & $\%$ \\
\hline 3 Orang & 46.2 & 46.2 & 7.6 & 100.0 \\
< 5 Orang & 28.6 & 71.4 & 0.0 & 100.0 \\
$\geq$ 5 Orang & 50.0 & 50.0 & 0.0 & 100.0
\end{tabular}

Keterangan: Uji chi square: nilai signifikansi $=0.405$

Berdasarkan Tabel 12 terlihat bahwa tidak ada kecenderungan hubungan, terbukti bahwa pada kelompok produktif terdapat pada tanggungan keluarga tiga orang. Hal ini karena, pada keluarga nelayan walaupun tanggungan keluarga hanya tiga orang tetapi kebutuhan mereka tetap besar. Rata-rata anaknya bersekolah semua sehingga istri nelayan lebih fokus pada pekerjaan produktif karena disamping untuk membantu memenuhi kebutuhan rumah tangga tetapi juga untuk biaya anak mereka sekolah.

\section{Hubungan Karakteristik dan Peran Kerja Istri Nelayan dengan Kontribusi Perempuan Dalam Pendapatan Rumah Tangga}

\section{Hubungan Usia dengan Pendapatan Perempuan}

Faktor yang memengaruhi keterlibatan wanita nelayan dalam kegiatan ekonomi adalah usia. Usia seseorang cenderung ikut memengaruhi dalam kontribusi pendapatan, semakin bertambah usia seseorang maka semakin tinggi kontribusi tersebut.

Pada Tabel 13 terlihat bahwa tidak ada kecenderungan, terbukti bahwa kontribusi pendapatan perempuan lebih dominan pada tingkat usia yaitu dewasa menengah dengan kontribusi sedang. Berdasarkan tabel tersebut terlihat bahwa jika usia responden dewasa maka kontribusinya cenderung tinggi, sedangkan jika usia responden tua maka kontribusinya cenderung rendah. Hal ini dapat kita ketahui bahwa dengan usia dewasa maka perempuan masih semangat dan giat untuk bekerja, beda halnya apabila usia sudah tergolong tua maka perempuan sudah tidak mementingkan pekerjaan karena faktor usia dan sudah tidak kuat untuk bekerja yang terlalu menguras tenaga mereka.

Tabel 13 Jumlah dan persentase responden berdasarkan usia dengan kontribusi pendapatan perempuan, Desa Cidadap, Palabuhan Ratu, Kabupaten Sukabumi, tahun 2017

\begin{tabular}{lcccc}
\hline & \multicolumn{3}{c}{ Kontribusi Pendapatan } \\
& \multicolumn{3}{c}{ Perempuan (\%) } & \multirow{2}{*}{ Total } \\
\cline { 2 - 4 } & Usia & Rendah & Sedang & Tinggi \\
\cline { 2 - 4 } & $\%$ & $\%$ & $\%$ & $\%$ \\
\hline Dewasa Muda & 33.3 & 33.3 & 33.3 & 100.0 \\
Dewasa Menengah & 13.3 & 63.3 & 23.3 & 100.0 \\
Tua & 57.0 & 43.0 & 0.0 & 100.0 \\
\hline Uji chi square: nilai signifikansi $=0.108$ & &
\end{tabular}

\section{Hubungan Pendidikan dengan Kontribusi Pendapatan Perempuan}

Tingkat pendidikan seorang perempuan dapat pula mencerminkan penguasaan cakrawala dalam cara berfikir dan bertindak yang rasional. Semakin tinggi tingkat pendidikan seseorang, maka akan semakin mampu menangkap kesempatan ekonomi yang lebih baik disekitarnya, dengan pendidikan semakin tinggi juga akan meningkatkan mutu kerja sekaligus meningkatkan produktivitasnya.

Tabel 14 Persentase responden berdasarkan tingkat pendidikan dengan kontribusi pendapatan perempuan, Desa Cidadap, Palabuhan Ratu, Kabupaten Sukabumi, tahun 2017

\begin{tabular}{lcccc}
\hline Pendidikan & \multicolumn{3}{c}{ Kontribusi Pendapatan } & \multirow{2}{*}{ Total } \\
& \multicolumn{3}{c}{ Perempuan (\%) } & \\
\cline { 2 - 4 } & Rendah & Sedang & Tinggi & \\
\cline { 2 - 4 } & $\%$ & $\%$ & $\%$ & $\%$ \\
\hline Rendah & 0.0 & 86.0 & 14.0 & 100.0 \\
Sedang & 29.0 & 46.0 & 25.0 & 100.0 \\
Tinggi & 22.0 & 67.0 & 11.0 & 100.0 \\
\hline
\end{tabular}

Uji chi square: nilai signifikansi $=0.344$

Pada Tabel 14 terlihat bahwa tidak ada kecenderungan hubungan, terbukti bahwa kontribusi paling dominan terdapat pada tingkat pendidikan rendah dengan kontribusi yaitu sedang. Berdasarkan Tabel tersebut terlihat jelas memperlihatkan bahwa antara variabel pendidikan dan variabel kontribusi perempuan tidak memiliki hubungan karena tinggi 
rendahnya pendidikan tidak memengaruhi semangat kerja para perempuan di Desa Cidadap, karena tidak ada syarat dalam pekerjaan yang mereka tekuni untuk hal pendidikan mereka sendiri.

Tabel 15 Jumlah dan persentase responden berdasarkan jenis pekerjaan responden dengan kontribusi pendapatan perempuan, Desa Cidadap, Palabuhan Ratu, Kabupaten Sukabumi, tahun 2017

\begin{tabular}{lcccc}
\hline & \multicolumn{3}{c}{ Kontribusi Pendapatan } \\
Jenis & \multicolumn{3}{c}{ Perempuan (\%) } & Total \\
\cline { 2 - 4 } $\begin{array}{c}\text { Pekerjaan } \\
\text { Perempuan }\end{array}$ & Rendah & Sedang & Tinggi & \\
\cline { 2 - 4 } & $\%$ & $\%$ & $\%$ & $\%$ \\
\hline Buruh & 28.0 & 67.0 & 5.0 & 100.0 \\
Berusaha & 20.0 & 55.0 & 25.0 & 100.0 \\
Sendiri & 0.0 & 0.0 & 100.0 & 100.0 \\
Ganda & & & &
\end{tabular}

Uji chi square: nilai signifikansi $=0.030$

Pada Tabel 15 terlihat bahwa ada kecenderungan hubungan, terbukti bahwa kontribusi pendapatan perempuan yang tinggi terdapat pada jenis pekerjaan yaitu pekerjaan ganda. Hal ini karena istri nelayan di Desa Cidadap yang memiliki pekerjaan ganda memiliki pendapatan yang relatif tinggi. Pekerjaan ganda yang mereka kerjakan antara lain adalah buruh cuci dengan buruh tani dan jualan gorengan dengan buruh tani. Mereka rutin mengerjakan pekerjaan tersebut setiap harinya karena suami mereka hanya mendapatka uang Rp.50.000 per hari sehingga mereka yang bergerak untuk ikut serta memenuhi kebutuhan rumah tangganya.

Tabel 16 Persentase responden berdasarkan pekerjaan suami dengan kontribusi pendapatan perempuan, Desa Cidadap, Palabuhan Ratu, Kabupaten Sukabumi, tahun 2017

\begin{tabular}{lcccc}
\hline & \multicolumn{3}{c}{ Kontribusi Pendapatan } \\
Perempuan (\%) & \multirow{2}{*}{ Total } \\
\cline { 2 - 4 } Pekerjaan Suami & Rendah & Sedang & Tinggi & \\
\cline { 2 - 4 } & $\%$ & $\%$ & $\%$ & $\%$ \\
\hline $\begin{array}{l}\text { Buruh Nelayan } \\
\text { Nelayan dengan }\end{array}$ & 0.0 & 65.0 & 35.0 & 100.0 \\
$\begin{array}{l}\text { Usaha } \\
\text { Sampingan }\end{array}$ & & 50.0 & 5.0 & 100.0 \\
\hline Ujlchi & & & & \\
\hline
\end{tabular}

Uji chi square: nilai signifikansi $=0.001$

Pada tabel di atas terlihat bahwa ada kecenderungan hubungan, terbukti bahwa pekerjaan buruh nelayan mayoritas memiliki kontribusi perempuan yang sedang, sedangkan pekerjaan buruh nelayan dengan usaha sampingan mayoritas memiliki kontribusi perempuan yang rendah sampai sedang. Hal ini karena, di Desa Cidadap suami yang memilih untuk memiliki pekerjaan sampingan adalah suami yang pendapatannya kecil sehingga mereka mencari pekerjaan lain untuk dapat sedikitnya menambah pendapatan mereka. Beda halnya dengan yang bekerja sebagai buruh nelayan saja, mereka tidak mencari pekerjaan sampingan karena pendapatannya mereka rasa cukup untuk memenuhi kebutuhan rumah tangganya. walaupun para istri berpendapat bahwa pendapatan suami mereka masih bisa di katakan kurang untuk memenuhi kebutuhan hidup rumah tangga mereka.

Tabel 17 Persentase responden berdasarkan jumlah tanggungan keluarga dengan kontribusi pendapatan perempuan, Desa Cidadap, Palabuhan Ratu, Kabupaten Sukabumi, tahun 2017

\begin{tabular}{|c|c|c|c|c|}
\hline \multirow{3}{*}{$\begin{array}{c}\text { Jumlah } \\
\text { Tanggungan } \\
\text { Keluarga } \\
\text { (Orang) }\end{array}$} & \multicolumn{3}{|c|}{$\begin{array}{l}\text { Kontribusi Pendapatan } \\
\text { Perempuan (\%) }\end{array}$} & \multirow{2}{*}{ Total } \\
\hline & Rendah & Sedang & Tinggi & \\
\hline & $\%$ & $\%$ & $\%$ & $\%$ \\
\hline 3 & 18.0 & 82.0 & 0.0 & 100.0 \\
\hline$<5$ & 25.0 & 50.0 & 25.0 & 100.0 \\
\hline$\geq 5$ & 23.0 & 46.0 & 31.0 & 100.0 \\
\hline
\end{tabular}

Uji chi square: nilai signifikansi $=0.056$

Pada tabel di atas terlihat bahwa tidak ada kecenderungan hubungan, terbukti bahwa kontribusi pendapatan perempuan dominan terdapat pada jumlah tanggungan keluarga yaitu tiga dengan kontribusi sedang. Hal ini karena, pada keluarga nelayan walaupun tanggungan keluarga hanya tiga orang tetapi kebutuhan mereka tetap besar. Rata-rata anaknya bersekolah semua, sehingga istri nelayan lebih fokus pada pekerjaan karena disamping untuk membantu memenuhi kebutuhan rumah tangga tetapi juga untuk biaya anak mereka sekolah.

\section{SIMPULAN DAN SARAN}

\section{Simpulan}

Menurut penelitian ini, maka dapat ditarik kesimpulan, pertama Karakteristik istri nelayan merupakan hal-hal yang perlu diperhatikan dalam melihat peran kerja dan kontribusi perempuan dalam pendapatan rumah tangga. Pada karateristik individu sebanyak 40 responden dengan klasifikasi berdasarkan umur mayoritas berada pada golongan 
usia 26-45 tahun. Tingkat pendidikan formal dominan responden tergolong kategori sedang yaitu tamat SD sampai tidak tamat SMP sebesar 62.5 persen, sedangkan pada jenis pekerjaan responden mayoritas yakni berusaha sendiri. Jumlah tanggungan keluarga pada karakteristik rumah tangga responden mayoritas (40\%). Kedua, Kelima variabel pengukur untuk mengukur peran kerja perempuan (berdasarkan lama jam kerja) tidak ada variabel yang memiliki kecenderungan hubungan dengan peran kerja. Dan ketiga, Hubungan karakteristik dan peran kerja dengan kontribusi perempuan dalam pendapatan rumah tangga dari hasil penelitian di Desa Cidadap dapat ditarik kesimpulan bahwa dari kelima variabel pengukur untuk mengukur kontribusi pendapatan perempuan ada variabel yang memiliki kecenderungan dengan kontribusi pendapatan perempuan yaitu jenis pekerjaan istri dan pekerjaan suami.

\section{Saran}

Saran dari penelitian ini yaitu karena pentingnya kontribusi pendapatan perempuan untuk menjaga kontinuitas pendapatan rumah tangga khususnya rumah tangga nelayan maka perlu adanya pembentukan kelompok istri nelayan sebagai wadah pelatihan untuk meningkatkan keterampilan pada kegiataan yang sudah dilakukan maupun kegiatan baru (individu maupun kelompok) bagi para istri nelayan yang berkaitan dengan usaha yang dapat meningkatkan pendapatan. Modal yang cukup sangat diperlukan untuk meningkatkan sumbangan pendapatan istri nelayan terutama pada strata istri nelayan yang suaminya sebagai buruh nelayan. Untuk itu perlu kebijaksanaan penyediaan kredit kecil dengan persyaratan yang mudah dan tidak memberatkan, baik melalui lembaga perkoperasian maupun lembaga lainnya mengingat flukluasi kegiatan nelayan. Selain itu, buruh nelayan perlu memiliki usaha sampingan sehingga dapat memenuhi kebutuhan rumah tangga dan tidak tergantung pada istri.

\section{DAFTAR PUSTAKA}

[BPS] Badan Pusat Statistik. 2014. Jumlah Rumah Tangga Perikanan Tangkap Menurut Provinsi dan Subsektor. [Internet]. [Diunduh tanggal 03 April 2017]. Tersedia pada: http://www.bps.go.id/linkTabelStatis/view/id/1709.

Aswiyati I. 2016. Peran Wanita Dalam Menunjang Perekonomian Rumah Tangga Keluarga Petani
Tradisional untuk Penanggulangan Kemiskinan di Desa Kuwil Kecamatan Kalawat [skripsi]. Manando (ID): Universitas Sam Ratulangi[Internet]. [Diunduh tanggal : 10 November 2016]. Tersedia pada:http://ejournal.unsrat.ac.id/index.php/holistik/ article/download/11188/10778.

Bahri. 1995. Pembangunan dan Strategi Memerangi Kemiskinan. Yogyakarta (ID). Liberty.

Boserup E. 1984. Peranan Wanita dalam Perkembangan Ekonomi. Jakarta (ID): Yayasan Obor Indonesia.

Dewi PM. 2012. Partisipasi Tenaga Kerja Perempuan dalam Meningkatkan Pendapatan Keluarga. Jurnal Ekonomi Kuantitatif Terapan (VI) [Internet]. [Diunduh tanggal 15 Maret 2017]; Vol. 5 (2). Tersedia pada:

Djuwita D. 2012. Peran Perempuan Masyarakat Pesisir dalam Meningkatkan Pendapatan Keluarga Nelayan di Desa Mertasinga[Skripsi]. Cirebon (ID). IAIN Syekh Nurjati Cirebon [internet]. [diunduh pada tanggal : 10 November 2016]. Tersedia pada: http://www.syekhnurjati.ac.id/jurnal/index.php/am wal/article/download 203/178.

Farida L. 2011. Kontribusi Pendapatan Perempuan Bekerja Sektor Informal Pada Ekonomi Keluarga di Kota Pekanbaru. Jurnal Aplikasi Bisnis[Internet]. [diunduh tanggal 10 November 2016]. Vol. 1, No. 2. Tersedia pada: http://www.ijhinet.com/journals/Vol_2_No_1_Ap ril_2011/103.pdf.

Gilarso T. 2004. Pengantar Ilmu Ekonomi Makro. Yogyakarta (ID). Karnisius.

Handayani MT, Artini NWP. 2009. Kontribusi Pendapatan Ibu Rumah Tangga Pembuat Makanan Olahan terhadap Pendapatan Keluarga. Piramida [Internet]. [diunduh tanggal 10 November 2016]; Volume V(1) Juli 2009. Tersedia pada: http://ojs.unud.ac.id/index.php/piramida.

Haryanto S. 2008. Peran Aktif Wanita dalam Peningkatan Pendapatan Rumah Tangga Miskin: Studi Kasus pada Wanita Pemecah Batu di Pucanganak Kecamatan Tugu Trenggalek. Jurnal Ekonomi Pembangunan [Internet]. [diunduh tanggal 15 September 2015, pukul 16.09 WIB]. Vol. 9 (2). Tersedia pada: https://publikasiilmiah.ums.ac.id/bitstream/handle/ 11617/155/6.Sugeng

Kharisun M. 2014. Karakteristik dan Peran Istri Nelayan dalam Pendapatan Nelayan di Kota Pekalongan [skripsi]. Semarang (ID). Universitas Diponegoro[internet]. [diunduh tanggal 8 April 2017]. Tersedia pada: http://eprints.undip.ac.id/43130/1/09_KHA RISUN.pdf.

Kusnadi. 2006. Pemberdayaan Perempuan Pesisir. Yogyakarta (ID): LKis.

Linda W. 2008. Analisis Kontribusi Pendapatan Nelayan di Kelurahan Pasie Nan Tigo Kecamatan Koto 
Tangah Kota Padang [skripsi]. Padang (ID). Universitas Bung Hatta[internet]. [diunduh tanggal $8 \quad$ April 2017]. Tersedia pada: http://eprints.bunghatta.ac.id/43130/1/09_LI NDA.W.pdf.

Saptari R, B Holzner. 1997. Perempuan Kerja dan Perubahan sosial: sebuah Pengantar Studi Perempuan. Jakarta (ID): Grafiti and Kalyanamitra.

Sari RS. 2014. Kontribusi Pendapatan Ibu Rumah Tangga Penjahit Kain Perca terhadap Pendapatan Total Keluarga. Jurnal FKIP Universitas Lampung[Internet]. [Diunduh tanggal 16 Maret 2017]; Vol. 2(5). Tersedia pada: http://jurnal.fkip.unila.ac.id/index.php/JPG/article /view/5625/3496. 